\title{
KOMPONEN KIMIA SEPULUH JENIS KAYU TANAMAN DARI JAWA BARAT
}

\section{(Chemical Component of Ten Planted Wood Species Originated from West Java)}

\author{
Oleh/By : \\ Gustan Pari $^{(1)}$, Han Roliadi' ${ }^{1)}$ Dadang Setiawan ${ }^{2)}$ \& Saepuloh ${ }^{2)}$
}

\begin{abstract}
This paper reported the chemical component of ten wood species originated from West Java. There were ki sereh (Cinnamomum parthenoxylon Meissu), suren (Toona sureni Merr), ki bawang (Melia excelsa Jack.), pulai kongo (Alstonia kongoensis), tusam (Pinus merkusii Jungth), sengon buto (Entorolobium cyclo), kapur (Dryobalanops aromatica), salamander (Grevillia robusta A.cunn), mahoni (Switenia macrophylla King) dan ki lemo (Litsea cubeba Pers).

The analysis quantified holocellulose, lignin, pentosan and ash contents. The properties analysis including the solubility in alcohol benzene, cold water, hot water and solubility in $1 \% \mathrm{NaOH}$. These analysis were conducted to determine their basic characteristics and the ultimate uses of wood material, especially forpulp manufacturing.

The result showed that the holocellulose content ranged from 64.6-69.9\%, lignin from $26.0-30.9 \%$, pentosan from $15.6-18 \%$, ash content from $0.2-0.9 \%$, silica content from $0.1-0.5 \%$, respectively. The solubility in cold water from $2.3-6.3 \%$, hot water from $3.0-7.3 \%$, alcohol benzene from $1.5-5.7 \%$ and the solubility in $1 \% \mathrm{NaOH}$ from $9.1-20.7 \%$, respectively.

All of wood species had high holocellulose content which is more than 65\%, the wood species were ki sereh, suren, ki bawang, tusam, sengon buto, kapur, salamander, mahoni and ki lemo, except pulai kongo wood species was $64.6 \%$. The lignin and ash contents from all of wood species had moderate between $18-33 \%$ for lignin and $0.2-6.0 \%$ for ash contents. All of wood species had low pentosan content which is less than 21\%. Extractive content, especially the soblubility of alcohol benzene four wood species had moderate contents i.e suren, ki bawang, tusam and ki lemo. Four wood species had low contents i.e sengon buto, kapur, salamander and mahoni. Two wood species had high contents i.e ki sereh andpulaikongo.

Based on chemical analysis, especially the highest holocellulose content, the lowest of lignin, ash and extractive contents, ki sereh and pulai kongo wood species are not suitable for making pulp andpaper, but the other eight wood species i.e: suren, ki bawang, tusam, sengon buto, kapur, salamander, mahoni and ki lemo are suitable as a raw material for pulp and paper industry with chemical, and semi chemical process.
\end{abstract}

Keywords: Wood, chemical, lignin, holocellulose, pentosan.

\footnotetext{
${ }^{10}$ Peneliti pada Pusat Penelitian dan Pengembangan Hasil Hutan, Bogor

${ }^{2)}$ Teknisi pada Pusat Penelitian dan Pengembangan Hasil Hutan, Bogor
} 


\begin{abstract}
ABSTRAK
Tulisan ini mengemukakan hasil analisis komponen kimia 10 jenis kayu yang berasal dari hutan tanaman di Jawa Barat. Jenis kayu tersebut adalah ki sereh (Cinnamomum parthenoxylon Meissu), suren (Toona sureni Merr), ki bawang (Melia excelsa Jack.), pulai kongo (Alstonia kongoensis), tusam (Pinus merkusii Jungth), sengon buto (Entorolobium cyclo), kapur (Dryobalanops aromatica), salamander (Grevillia robusta A.cunn), mahoni (Switenia macrophylla King) dan ki lemo (Litsea cubeba Pers).

Analisis yang dilakukan mencakup penetapan kadar holoselulosa, lignin, pentosan, abu, kelarutan dalam air dingin, air panas, alkohol benzena dan kelarutan dalam $\mathrm{NaOH} 1 \%$. Analisis ini merupakan dasar untuk menetapkan kegunaan kayu tersebut terutama sebagai bahan baku pulp kertas.

Hasil analisis memperlihatkan bahwa kadar holoselulosa berkisar antara 64,6 - 69,9\%, lignin antara 26,0 - 30,9\%, pentosan antara $15,6-18 \%$, abu antara $0,2-0,9 \%$, silika antara $0,1-0,5 \%$. Kelarutan dalam air dingin antara 2,4 - 6,3\%, air panas antara 3,0 - 7,3\%, alkohol benzena antara 1,5 $5,75 \%$ dan kelarutan dalam $\mathrm{NaOH} 1 \%$ antara $9,1-20,7 \%$.

Semua jenis kayu yang diteliti mengandung kadar holoselulosa yang tinggi lebih dari $65 \%$ yaitu kayu ki sereh, suren, ki bawang, tusam, sengon buto, kapur, salamander, mahoni dan ki lemo, kecuali kayu pulai kongo yaitu 64,6\%. Kadar lignin dan abu semua jenis kayu yang diteliti termasuk ke dalam kelas sedang, karena kadarnya ada di antara 18 - 33\% untuk kadar lignin dan ada di antara 0,2 - 6,0\% untuk kadar abu. Kadar pentosan semua jenis kayu yang diteliti termasuk kelas rendah karena kadarnya kurang dari $21 \%$. Sedangkan kadar zat ekstraktifnya terutama kelarutan dalam alkohol benzena yang termasuk kelas sedang antara $2-4 \%$ adalah kayu suren, ki bawang, tusam dan ki lemo, dan yang termasuk ke dalam kelas tinggi lebih dari $4 \%$ yaitu kayu ki sereh dan pulai kongo, sedangkan yang termasuk kelas rendah kurang dari $\%$ yaitu kayu sengon buto, kapur, salamander dan mahoni.

Berdasarkan atas nilai skor dan hasil uji BNJ (Beda nyata jujur) komponen kimia 10 jenis kayu asal Jawa Barat (Tabel 3) ternyata hanya kayu ki sereh dan pulai kongo yang tidak cocok untuk bahan baku pulp kertas, sedangkan ke delapan jenis kayu lainnya yang terdiri dari kayu suren, ki bawang, tusam, sengon buto, kapur, salamander mahoni dan kayu ki lemo cukup baik untuk digunakan sebagai bahan baku pembuatan pulp untuk kertas dengan menggunakan proses kimia, dan semikimia.
\end{abstract}

Kata kunci : Kayu, kimia, lignin, holoselulosa, pentosan.

\title{
I. PENDAHULUAN
}

Penelitian sifat dasar untuk berbagai jenis kayu dari seluruh Indonesia dilakukan setiap tahun di Pusat Penelitian dan Pengembangan Hasil Hutan Bogor, dengan tujuan untuk mengetahui kandungan komponen kimia kayu yang berasal dari hutan tanaman dan hutan alam. Hal ini dikarenakan dari 4.000 jenis kayu yang ada di Indonesia baru sekitar 5\% yang sudah diidentifikasi sifat dasarnya yaitu sifat anatomi, sifat fisik mekanik dan kimia.

Di pihak lain, keberadaan kayu komersial yang berasal dari hutan alam maupun tanaman seperti meranti, kamper, eboni, jati, merbau dan ulin semakin langka, oleh karena itu perlu dicari sumber bahan baku alternatif untuk keperluan industri penggergajian, kayu lapis, pulp kertas dan energi, sehingga perlu dilakukan penelitian sifat dasar dari jenis-jenis tersebut. Salah satu penelitian sifat dasar adalah penelitian mengenai kandungan komponen kimia kayu seperti holoselulosa, lignin, pentosan dan zat ekstraktif. Diharapkan, hasil penelitian jenis kayu dari hutan tanaman Jawa Barat ini dapat mempertegas pemanfaatan 10 jenis kayu tersebut sebagai bahan baku pulp untuk kertas. 


\section{BAHAN DAN METODE}

\section{A. Lokasi Penelitian}

Penelitian sifat dasar 10 jenis kayu ini dilakukan di Laboratorium Kimia Kayu dan Energi, Kelompok Peneliti Pengolahan Kimia dan Energi Hasil Hutan, Pusat Penelitian dan Pengembangan Hasil Hutan Bogor.

\section{B. Bahan dan Peralatan}

Bahan penelitian terdiri dari 10 jenis kayu yang berasal dari hutan tanaman di Jawa Barat. Jenis kayu tersebut adalah ki sereh (Cinnamomum parthenoxylon Meissu), suren (Toona sureni Merr), ki bawang (Melia excelsa Jack.), pulai kongo (Alstonia kongoensis), tusam (Pinus merkusii Jungth), sengon buto (Entorolobium cyclo), kapur (Dryobalanops aromatica), salamander (Grevillia robusta A.cunn), mahoni (Switenia macrophylla King) dan ki lemo (Litsea cubeba Pers).

Bahan kimia yang digunakan yaitu alkohol, benzena, asam asetat, asam klorida, air suling, natrium hidroksida dan lain-lain. Peralatan yang digunakan antara lain neraca analitik, oven, tanur, ayakan, mesin giling, golok, kantong plastik, penangas air serta alat gelas/alat kaca lainnya.

\section{Metode Penelitian}

Setiap contoh yang diambil dari campuran bagian batang atas, tengah dan bawah, digiling dan diayak sampai didapat serbuk kayu yang lolos saringan 40 mesh dan tertahan pada saringan 60 mesh. Hasil saringan dipakai sebagai sampel untuk analisis kandungan komponen kimianya.

Analisis komponen kimia kayu yang dilakukan mengikuti standar TAPPI. TAPPI T13 wd-74 (Anonim, 1993) untuk penetapan kadar lignin dan standar ASTM D 1102 (Anonim, 1995) untuk penetapan kadar abu. Alkohol benzena ditetapkan mengikuti standar ASTM D 1107), kelarutan dalam $\mathrm{NaOH} 1 \%$ menurut ASTM D 1109, kelarutan dalam air dingin dan air panas menurut ASTM D 1110 (Anonim, 1995). Untuk kadar pentosan dilakukan dengan metoda gravimetri menggunakan phloroglusinol (Wise, 1944) dan penetapan holoselulosa dengan natrium khlorit (Young, 1972).

\section{Metode Analisis Data}

Untuk menelaah data sifat kimia dari 10 jenis kayu tersebut, digunakan rancangan acak lengkap satu faktor. Sebagai faktor atau perlakuan adalah 10 jenis kayu. Apabila terdapat pengaruh yang nyata terhadap perlakuan sifat kimia tertentu dari 10 jenis kayu, maka untuk mengetahui jenis kayu yang memiliki komponen yang baik untuk bahan baku pulp kertas dilakukan uji jarak beda nyata jujur (Sudjana, 1980).

\section{HASIL DAN PEMBAHASAN}

\section{A. Holoselulosa}

Kadar holoselulosa berkisar antara 64,6 - 69,9\% (Tabel 1). Berdasarkan hasil analisis keragaman (Tabel 2) dan hasil uji jarak beda nyata jujur (BNJ) ternyata kadar holoselulosa 10 
jenis kayu tersebut dari yang tertinggi hingga terendah dapat dikelompokkan menjadi 6 kelompok (Tabel 3). Kadar holoselulosa terendah di antaranya terdapat pada kayu pulai kongo $(64,6 \%)$, dan kadar yang tertinggi di antaranya terdapat pada kayu ki bawang $(69,9 \%)$. Kadar holoselulosa yang rendah memberi gambaran bahwa rendemen bubur kayu yang dihasilkan akan rendah, dan sebaliknya makin tinggi kandungan holoselulosa dalam kayu akan memudahkan terbentuknya sifat hidrofilik pulp sehingga memudahkan terjadinya ikatan antar serat. Selain itu dalam pembuatan arang aktif akan dihasilkan struktur lapisan kristalit heksagonal yang lebih banyak dibandingkan dengan kayu yang kadar holoselulosanya rendah (Pari, 2004). Apabila dilihat dari kadar holoselulosa saja, maka semua jenis kayu yang diteliti sangat baik sebagai bahan baku pembuatan bubur kayu karena kadar holoselulosanya lebih dari 65\%, dan untuk proses pembuatan bubur kayu sebaiknya menggunakan proses kimia (Anonim, 1980).

\section{B. Lignin}

Kadar lignin berkisar antara 26,0 - 30,9\% (Tabel 1). Berdasarkan hasil analisis keragaman (Tabel 2) dan uji BNJ (Tabel 3), ternyata kadar lignin dapat dikelompokkan menjadi 3 kelompok dari yang tertinggi hingga terendah. Kadar lignin terendah diantaranya terdapat pada kayu mahoni $(26,0 \%)$ dan termasuk yang tertinggi terdapat pada kayu tusam $(30,9 \%)$. Tingginya kadar lignin akan berpengaruh pada banyaknya pemakaian bahan kimia pada waktu proses delignifikasi dalam pembuatan bubur kayu khususnya dengan proses kimia atau semikimia. Namun sebaliknya kandungan lignin yang tinggi ini sangat baik untuk dibuat briket arang yang dilakukan dengan cara kempa ulir panas pada waktu pembuatan briket kayunya. Apabila dihubungkan dengan klasifikasi komponen kimia kayu Indonesia untuk kayu daun lebar (Tabel 4) maka semua jenis kayu yang diteliti termasuk ke dalam kelas sedang karena kandungan ligninnya ada diantara 18 - 33\%. Khusus kayu dengan kadar lignin kurang dari $30 \%$, pembuatan bubur kayunya menggunakan proses semi kimia atau kimia dan untuk kayu dengan kadar lignin lebih dari 30\% sebaiknya menggunakan proses mekanik dalam pembuatan pulpnya (Anonim, 1980).

\section{Tabel 4. Klasifikasi komponen kimia kayu daun lebar Indonesia}

\section{Table 4. Chemical components classification of Indonesian hardwood species}

\begin{tabular}{|l|c|c|c|}
\hline \multirow{2}{*}{$\begin{array}{c}\text { Komponen kimia } \\
\text { (Chemical component) }\end{array}$} & \multicolumn{3}{|c|}{ Kelas komponen (Component classes) } \\
\cline { 2 - 4 }$\%$ & $\begin{array}{c}\text { Tinggi } \\
\text { (High) }\end{array}$ & $\begin{array}{c}\text { Sedang } \\
\text { (Moderate) }\end{array}$ & $\begin{array}{c}\text { Rendah } \\
(\text { Low })\end{array}$ \\
\hline Selulosa (Cellulose) & $>45$ & $40-45$ & $<40$ \\
Lignin (Lignin) & $>33$ & $18-33$ & $<18$ \\
Pentosan (Pentosan) & $>24$ & $21-24$ & $<21$ \\
Zat ekstraktif (Extractives) & $>4$ & $2-4$ & $<2$ \\
Abu (Ash) & $>6$ & $0,2-6$ & $<0,2$ \\
\hline
\end{tabular}

Sumber(Source) : Departemen Pertanian (Agriculture Ministry),1976 


\section{Pentosan}

Kadar pentosan berkisar antara 15,6 - 18\% (Tabel 1). Analisis keragaman (Tabel 2) dan uji BNJ (Tabel 3) menunjukkan bahwa berdasarkan kadar pentosan mulai dari yang tertinggi hingga terendah, 10 jenis kayu tersebut dapat dibuat menjadi 4 kelompok. Kadar pentosan yang terendah di antaranya terdapat pada kayu kapur (15,6\%) dan termasuk yang tinggi adalah pada kayu salamander $(18 \%)$. Kadar pentosan yang rendah sangat diharapkan dalam pembuatan pulp untuk rayon dan produk-produk lain turunan selulosa. Kandungan pentosan yang tinggi dalam pulp dapat menyebabkan kerapuhan benang rayon yang dihasilkan, sehingga pada saat pembentukan benang rayon mudah terputus. Juga sifat pentosan yang seperti gelatin dapat menimbulkan penyumbatan selama proses pembuatan viskosa yaitu bahan yang lebih lanjut diolah menjadi rayon. Demikian juga untuk pengolahan kayu menjadi arang, kadar pentosan yang tinggi dapat menurunkan rendemen arang. Ini karena pentosan merupakan polimer yang rantainya lebih pendek dibandingkan selulosa dan lignin, sehingga mudah terdegradasi oleh panas selama proses pengarangan. Sebaliknya dalam pengolahan pulp untuk produksi kertas adanya kadar pentosan yang tinggi akan memudahkan atau lebih mempersingkat lamanya waktu giling pulp. Apabila dihubungkan dengan klasifikasi komponen kimia daun lebar Indonesia (Tabel 4), maka semua jenis kayu yang diteliti termasuk ke dalam kelas dengan kandungan pentosan yang rendah karena kadarnya kurang dari 21\%. Jenis kayu yang mengandung pentosan yang rendah kurang baik digunakan untuk pembuatan pulp kertas dengan proses kimia, karena pulp sukar difibrilisasi sehingga waktu penggilingan menjadi lebih lama dan kekuatan serat pulpnya rendah. Apabila dibandingkan dengan kadar pentosan yang berasal dari hutan tropis Brasil, maka kadarnya relatif sama yaitu sebesar 14,5 4,2\% (Rowell, 1984).

\section{Zat Ekstraktif}

Kelarutan dalam air dingin, air panas dan alkohol benzena masing-masing berkisar antara 2,4 - 6,3\%; 3,0 - 7,3\% dan 1,5 - 5,7\% (Tabel 1). Hasil analisis keragaman (Tabel 2) dan uji BNJ (Tabel 3) menunjukkan bahwa atas dasar kelarutan dalam air dingin dari yang tertinggi hingga terendah, 10 jenis kayu tersebut dapat dibuat menjadi 5 kelompok, begitu juga dengan kelarutan dalam air panas dibagi menjadi 5 kelompok, dan berdasarkan kelarutan dalam alkohol benzena menjadi 6 kelompok. Komponen yang terlarut dalam air dingin adalah tanin, gum, gula dan pigmen, sedangkan yang terlarut dalam air panas adalah sama dengan yang terlarut dalam air dingin ditambah dengan komponen pati. Komponen yang terlarut dalam alkohol benzena adalah lemak, resin, bahan-bahan larut pelarut organik tidak polar atau sedikit memiliki polaritas (Anonim, 1995). Dalam pengolahan kayu menjadi pulp kertas adanya zat ekstraktif dapat mengakibatkan konsumsi larutan pemasak dan larutan pemutih menjadi lebih tinggi, dan juga pada lembaran kertasnya bisa menimbulkan masalah noda (pitch troubles).

Apabila dibandingkan dengan klasifikasi komponen kimia kayu daun lebar Indonesia (Tabel 4) terutama yang terlarut dalam alkohol benzena, maka kayu ki sereh $(5,0 \%)$ dan pulai kongo $(4,2 \%)$ termasuk ke dalam kelas yang mengandung kadar zat ekstraktif tinggi karena kadarnya lebih dari 4\%. Tingginya kadar zat ekstraktif ini akan menyulitkan penetrasi larutan kimia pemasak ke dalam dinding dan rongga sel kayu pada waktu proses pemasakan serpih kayu, sehingga diperlukan bahan kimia dan perekat yang lebih banyak. Sedangkan untuk kayu 
suren, ki bawang, tusam dan ki lemo termasuk ke dalam kelas yang mengandung kadar zat ekstraktif sedang, karena kadarnya ada di antara 2 - 4\% dan untuk kayu sengon buto, kapur, salamander dan mahoni termasuk ke dalam kelas rendah karena kadar zat ekstraktifnya kurang dari 2\% (Tabel 4). Didasarkan atas kandungan zat ekstraktif kayu dalam proses pembuatan pulp, kayu dengan kadar zat ekstratif kurang dari 5\% lebih baik menggunakan proses kimia dalam pembuatan bubur kayu (Anonim, 1980).

\section{E. Kelarutan dalam $\mathrm{NaOH} 1 \%$}

Kelarutan dalam NaOH 1\% berkisar antara 9,1 - 20,7\% (Tabel 1). Berdasarkan analiss keragaman (Tabel 2) dan uji BNJ (Tabel 3), terdapat 5 kelompok kelarutan dalam $\mathrm{NaOH}$ 1\% dari yang tertinggi hingga terendah. Kelarutan dalam $\mathrm{NaOH}$ ini dapat memberikan gambaran adanya kerusakan komponen kimia dinding sel kayu yang diakibatkan oleh serangan jamur pelapuk kayu atau terdegradasi oleh cahaya, panas dan oksidasi. Jadi semakin tinggi kelarutan dalam $\mathrm{NaOH}$ 1\%, tingkat kerusakan kayu juga meningkat. Kelarutan dalam $\mathrm{NaOH} 1 \%$ terendah terdapat pada kayu kapur $(9,1 \%)$ dan yang tertinggi terdapat pada kayu suren $(20,7 \%)$. Besarnya kelarutan dalam $\mathrm{NaOH} 1 \%$ ini akan menurunkan rendemen dan kualitas pulp (Anonim, 1995).

\section{F. Kadar Air}

Kadar air (atas dasar berat kering oven)10 jenis kayu yang diteliti berkisar antara 4.6 9.5\% (Tabel 1). Analisis keragaman (Tabel 2) dan uji BNJ (Tabel 3) memberi hasil bahwa berdasar kadar air, jenis kayu tersebut dari yang tertinggi hingga terendah dapat dibagi menjadi 4 kelompok yaitu kadar air antara 4,6 - 6,1\% (kelompok 1), 6,1 - 7,4\% (Kelompok 2), 7,4 - 8,3\% (kelompok 3) dan kadar air antara 8,3 - 9,7\% (kelompok 4). Kadar air yang dikandung suatu jenis kayu dapat mempengaruhi berat kayu dan akhirnya berpengaruh terhadap biaya angkut kayu. Demikian pula, kayu yang mengandung kadar air yang tinggi lebih mudah diserang organisme perusak kayu, sehingga mempercepat pelapukan kayu.

\section{G. Abu dan Silika}

Kadar abu dari sepuluh jenis kayu yang diteliti berkisar antara 0,2 - 0,9\% dan 0,1 - 0,5\% (Tabel 1). Analisis keragaman (Tabel 2) dan uji BNJ (Tabel 3) menunjukkan bahwa kadar abu terendah diantaranya terdapat pada kayu ki lemo $(0,2 \%)$ dan termasuk tertinggi adalah kayu sengon buto $(0,9 \%)$. Sedangkan untuk kadar silika, termasuk yang terendah adalah kayu suren $(0,05 \%)$ dan yang tertinggi adalah kayu kapur $(0,5 \%)$. Apabila dihubungkan dengan klasifikasi komponen kimia kayu daun lebar Indonesia (Tabel 4), maka semua jenis kayu yang diteliti termasuk ke dalam kelas dengan kandungan abu sedang, karena kadarnya ada diantara $0,2-6 \%$. Komponen yang terdapat dalam abu diantaranya adalah $\mathrm{K}_{2} \mathrm{O}, \mathrm{MgO}, \mathrm{CaO}, \mathrm{Na}_{2} \mathrm{O}$. Kadar abu yang tinggi tidak diharapkan dalam pembuatan pulp karena dapat mempengaruhi kualitas pulp kertas. Sedangkan besarnya kadar silika dalam kayu dapat mempercepat proses penumpulan pisau penyerpih dan mata gergaji kayu.

\section{H. Penelaahan Sifat Kimia Kayu Dihubungkan dengan Pemanfaataannya}

Pemanfaatan kayu menjadi pulp untuk kertas diharapkan kayu tersebut memiliki kadar 
holoselulosa dan pentosan yang tinggi sampai sedang, sedangkan kadar lignin, kadar abu, silika, kelarutan dalam pelarut netral atau polar, dan kelarutan dalam $\mathrm{NaOH} 1 \%$ yang rendah. Atas dasar total nilai skor dari hasil uji BNJ, komponen kimia dari 10 jenis kayu yang diteliti (Tabel 3) ternyata semakin tinggi total nilai skor maka semakin sesuai jenis kayu tersebut diolah menjadi pulp untuk kertas. Dari tabel 3 terlihat bahwa hanya jenis kayu mahoni dan suren tidak baik digunakan sebagai bahan baku pulp kertas, sedangkan jenis kayu ki sereh, ki bawang, pulai kongo, tusam, sengon buto, kapur, salamander dan ki lemo sangat baik untuk digunakan sebagai bahan baku pulp kertas dengan menggunakan proses kimia, dan semikimia.

\section{KESIMPULAN}

1. Kadar holoselulosa berkisar antara 64,6 - 69,9\%, lignin 26,0 - 30,9\%, pentosan 15,6 - 18\%, abu $0,2-0,5 \%$, silika $0,1-0,5 \%$. Kelarutan dalam air dingin $2,4-6,3 \%$, air panas 3,0 - 7,3\%, alkohol benzena antara 1,5 - 5,7\% dan kelarutan dalam $\mathrm{NaOH} 1 \%$ antara 9,1 - 20,7\%.

2. Jenis kayu yang diteliti mengandung kadar holoselulosa tinggi yaitu lebih dari $65 \%$ adalah kayu ki sereh, suren, ki bawang, tusam, sengon buto, kapur, salamander, mahoni dan ki lemo, kecuali kayu pulai kongo yaitu 64,6\%. Kadar lignin dan abu semua jenis kayu yang diteliti termasuk ke dalam kelas sedang, karena kadarnya ada di antara 18 33\% untuk kadar lignin dan ada di antara 0,2 - 6,0\% untuk kadar abu. Kadar pentosan semua jenis kayu yang diteliti termasuk kelas rendah karena kadarnya kurang dari 21\%. Sedangkan kadar zat ekstraktifnya terutama kelarutan dalam alkohol benzena yang termasuk kelas sedang antara 2 - 4\% adalah kayu suren, ki bawang, tusam dan ki lemo, dan yang termasuk ke dalam kelas tinggi lebih dari 4\% yaitu kayu ki sereh dan pulai kongo, sedangkan yang termasuk kelas rendah kurang dari $2 \%$ yaitu kayu sengon buto, kapur, salamander dan mahoni.

3. Berdasarkan atas tingginya kadar holoselulosa, rendahnya kadar lignin, zat ekstraktif dan kadar abu yang dikandung jenis kayu yang diteliti ternyata hanya jenis kayu suren dan mahoni yang tidak cocok untuk bahan baku kertas, sedangkan ke delapan jenis kayu lainnya yaitu ki sereh, mahoni, ki bawang, tusam, sengon buto, kapur, salamander, dan kayu ki lemo cukup baik untuk digunakan sebagai bahan baku pembuatan pulp untuk kertas dengan menggunakan proses kimia, dan semikimia.

\section{DAFTAR PUSTAKA}

Anonim. 1980. Guideline for utilization and marketing of tropical wood species. Food and Agricultural Organization of the United Nation. Rome.

. 1993. TAPPI test methods. Atlanta. Georgia.

1995. Annual book of ASTM Standards. Volume 04.10 wood. Section 4. Philadelphia. 
JURNAL Penelitian Hasil Hutan Vol. 24 No. 2, April 2006: 89-101

Departemen Pertanian. 1976. Vedemecum Kehutanan Indonesia, Balai Penjelidikan Kehutanan. Jakarta

Pari, G. 2004. Kajian struktur arang aktif dari serbuk gergaji kayu sebagai adsorben emisi formaldehida kayu lapis. Disertasi Pascasarjana, IPB. Bogor. Tidak diterbitkan

Rowell, R. 1984. The chemistry of solid wood. American Chemistry Society Washington.

Sudjana. 1980. Disain dan analisis eksperimen. Tarsito. Bandung.

Wise, L. E. 1944. Wood chemistry. Reinhold Publisher Corporation. New York.

Young, R. A. 1972. Wood chemistry laboratory procedure. University of Washington. Seattle, Washington. 


\begin{tabular}{|c|c|c|c|c|c|c|c|c|c|c|}
\hline 的 & $\overrightarrow{\vec{N}}$ & $\stackrel{n}{0}$ & $\stackrel{ \pm}{a}$ & $\stackrel{1}{a}$ & $\underset{0}{ت}$ & $\stackrel{I}{o}$ & $\stackrel{\infty}{+}$ & $\begin{array}{l}0 \\
0\end{array}$ & $\stackrel{0}{\circ}$ & $\hat{\sigma}_{0}$ \\
\hline 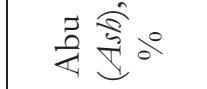 & సે & $\stackrel{\hat{\sigma}}{0}$ & 季 & $\stackrel{0}{0}$ & $\begin{array}{l}\text { ô } \\
\text { ô }\end{array}$ & $\stackrel{\check{\sigma}}{\sigma}$ & $\overrightarrow{\sigma_{0}}$ & $\hat{\sigma}_{0}$ & $\frac{t}{\sigma^{\prime}}$ & $\begin{array}{l}\stackrel{\leftrightarrow}{n} \\
\mathrm{O}^{2}\end{array}$ \\
\hline 专 $\mathrm{E}^{\mathrm{E}} \mathrm{o}^{\circ}$ & 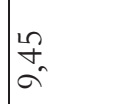 & $\hat{n}^{2}$ & $\stackrel{\overbrace{}^{2}}{\infty^{2}}$ & $\stackrel{1}{\stackrel{0}{0}}$ & $\begin{array}{l}\stackrel{n}{O}_{n} \\
\sigma^{\prime}\end{array}$ & $\begin{array}{l}: \\
\mathbb{\infty}^{n}\end{array}$ & $\overrightarrow{\sigma_{0}}$ & $\stackrel{\text { I }}{\sim}$ & $\vec{\sigma}$ & $\begin{array}{l}\hat{\sigma} \\
\dot{f}\end{array}$ \\
\hline 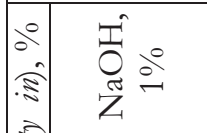 & $\begin{array}{l}2 \\
2 \\
n \\
n\end{array}$ & $\stackrel{n}{\hat{\imath}}$ & $\stackrel{\infty}{\stackrel{\infty}{n}}$ & 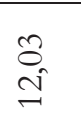 & $\stackrel{\infty}{m}_{a^{2}}$ & $\underbrace{\circ}_{0}$ & $\stackrel{ \pm}{a}$ & $\begin{array}{l}\infty \\
+\infty \\
\stackrel{+}{\leftarrow}\end{array}$ & $\begin{array}{l}\vec{E} \\
\infty \\
\infty\end{array}$ & 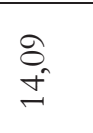 \\
\hline 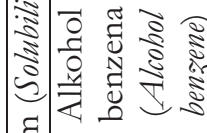 & $\mid \begin{array}{l}n \\
0 \\
\text { in }\end{array}$ & $\stackrel{2}{m}$ & $\begin{array}{l}8 \\
i \\
i\end{array}$ & 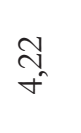 & $\stackrel{\text { f }}{n}$ & $\stackrel{+}{\stackrel{H}{=}}$ & $\stackrel{\infty}{\rightarrow}$ & $\stackrel{\substack{\infty \\
\rightarrow}}{\rightarrow}$ & $\stackrel{n}{\rightarrow}$ & $\overrightarrow{\tilde{\sigma}}$ \\
\hline 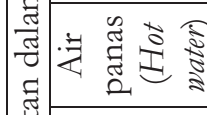 & $\frac{0}{m}$ & $\vec{E}$ & $\stackrel{\overbrace{}}{\stackrel{+}{+}}$ & $\begin{array}{l}i n \\
i n \\
i n\end{array}$ & $\stackrel{\infty}{+}$ & $\vec{r}$ & $\stackrel{i}{i}$ & $\hat{\sigma}$ & तु & $\hat{n}$ \\
\hline 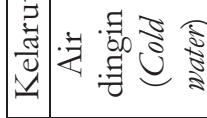 & $\begin{array}{l}8 \\
0 \\
i n\end{array}$ & 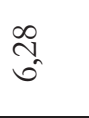 & s. & ڤ્ & $\begin{array}{l}\text { ळे } \\
\text { f }\end{array}$ & $\stackrel{\infty}{\sigma^{\prime}}$ & $\underset{m}{ \pm}$ & $\stackrel{\hat{N}}{\dagger}$ & $\stackrel{+}{n}$ & $\stackrel{\infty}{\stackrel{m}{m}}$ \\
\hline 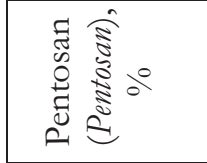 & \begin{tabular}{l}
0 \\
\multirow{6}{-1}{} \\
-1
\end{tabular} & $\begin{array}{l}\infty \\
\stackrel{\infty}{=}\end{array}$ & 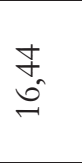 & 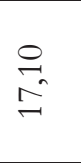 & $\begin{array}{l}0 \\
\stackrel{0}{=} \\
\stackrel{-}{-}\end{array}$ & 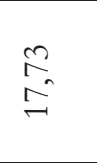 & $\begin{array}{l}\stackrel{n}{2} \\
\stackrel{n}{2} \\
\stackrel{n}{2}\end{array}$ & $\begin{array}{l}\infty \\
\stackrel{2}{\rightleftharpoons}\end{array}$ & $\stackrel{\circ}{\circ}$ & $\stackrel{n}{\stackrel{n}{\sigma}}$ \\
\hline . & fo & 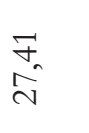 & $\stackrel{\vec{n}}{\stackrel{n}{N}}$ & $\stackrel{8}{\circ}$ & $\begin{array}{l}\infty \\
\infty \\
\infty \\
\infty\end{array}$ & $\begin{array}{l}\infty \\
\stackrel{\infty}{0} \\
\text { in }\end{array}$ & $\begin{array}{l}\text { nू } \\
\text { ô } \\
\text { ते }\end{array}$ & $\underset{\sim}{\stackrel{\sim}{n}}$ & $\begin{array}{l}8 \\
\text { i }\end{array}$ & $\begin{array}{l}\vec{\infty} \\
\dot{0} \\
\hat{N}^{n}\end{array}$ \\
\hline 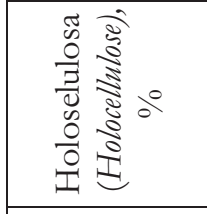 & \begin{tabular}{l}
7 \\
\multirow{2}{n}{} \\
0
\end{tabular} & 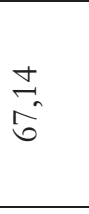 & $\begin{array}{l}\infty \\
\infty \\
a^{\circ}\end{array}$ & $\begin{array}{l}\stackrel{n}{n} \\
\stackrel{0}{0}\end{array}$ & 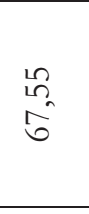 & $\overrightarrow{\hat{n}}$ & 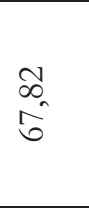 & $\begin{array}{l}\hat{\sigma} \\
\hat{\sigma}\end{array}$ & $\stackrel{n}{\stackrel{0}{0}}$ & $\begin{array}{l}3 \\
\tilde{b} \\
\tilde{b}\end{array}$ \\
\hline 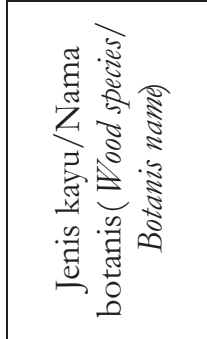 & 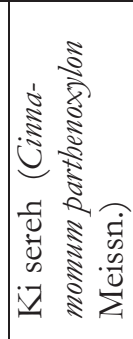 & 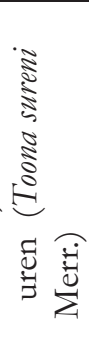 & 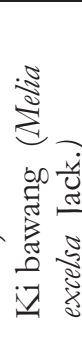 & 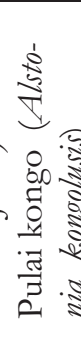 & 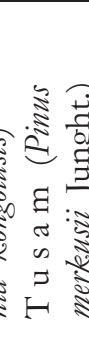 & 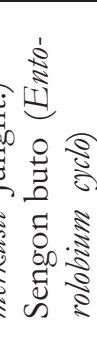 & 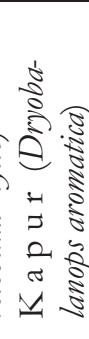 & 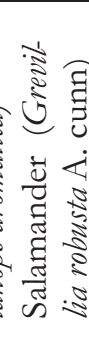 & 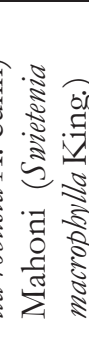 & 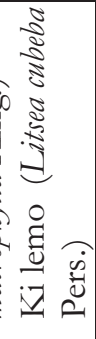 \\
\hline$\dot{z}$ & $\stackrel{-}{-}$ & $\dot{ن}$ & $\dot{r}$ & $\dot{\nabla}$ & $\dot{10}$ & $\dot{0}$ & $\stackrel{\circ}{\circ}$ & $\infty$ & $\sigma^{\circ}$ & $\stackrel{\ominus}{\ominus}$ \\
\hline
\end{tabular}


JURNAL Penelitian Hasil Hutan Vol. 24 No. 2, April 2006: 89-101

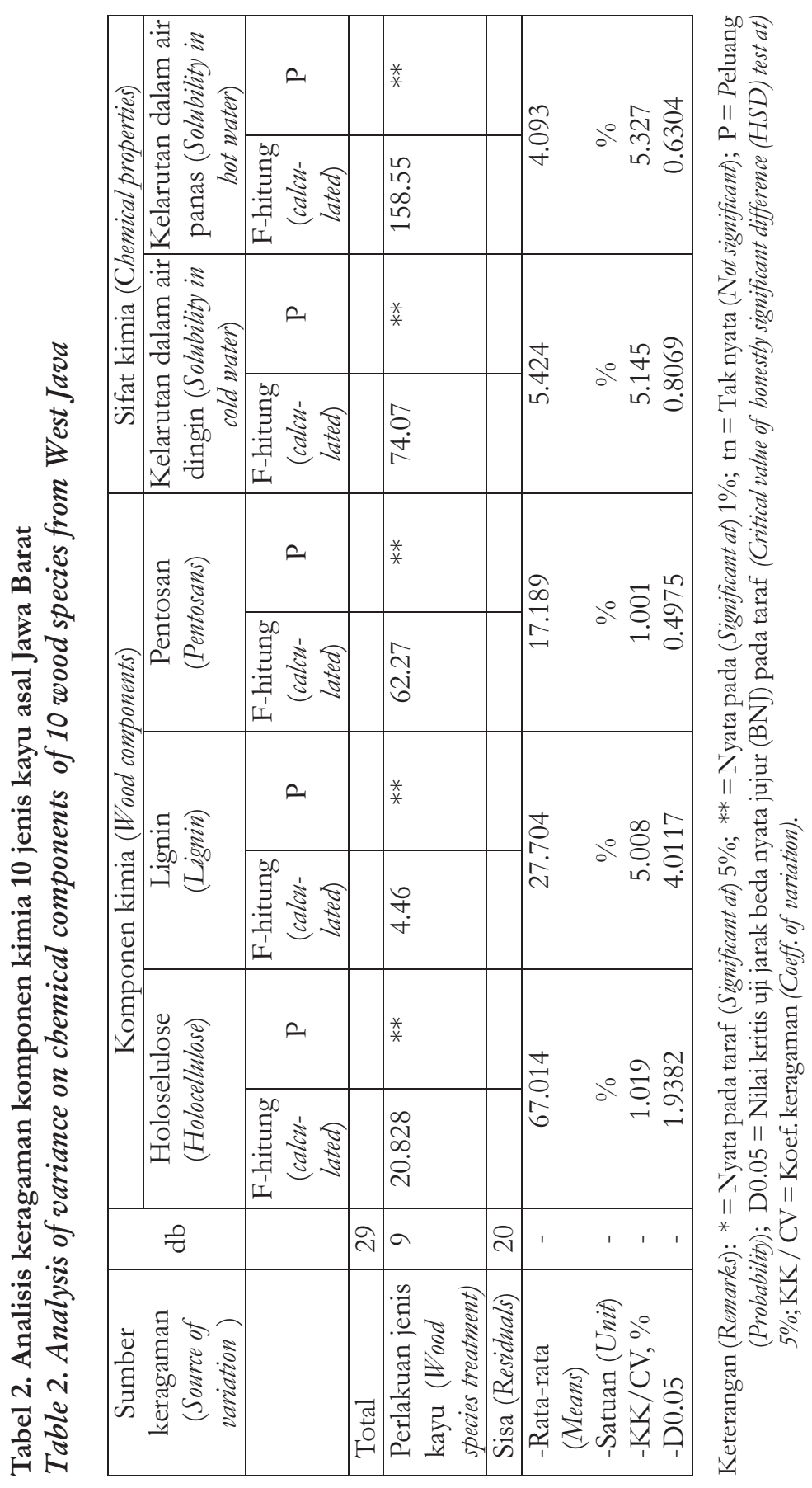


Komponen kimia sepuluh jenis kayu ... (Gustan Pari, Han Roliadi, Dadang Setiawan \& Saepuloh)

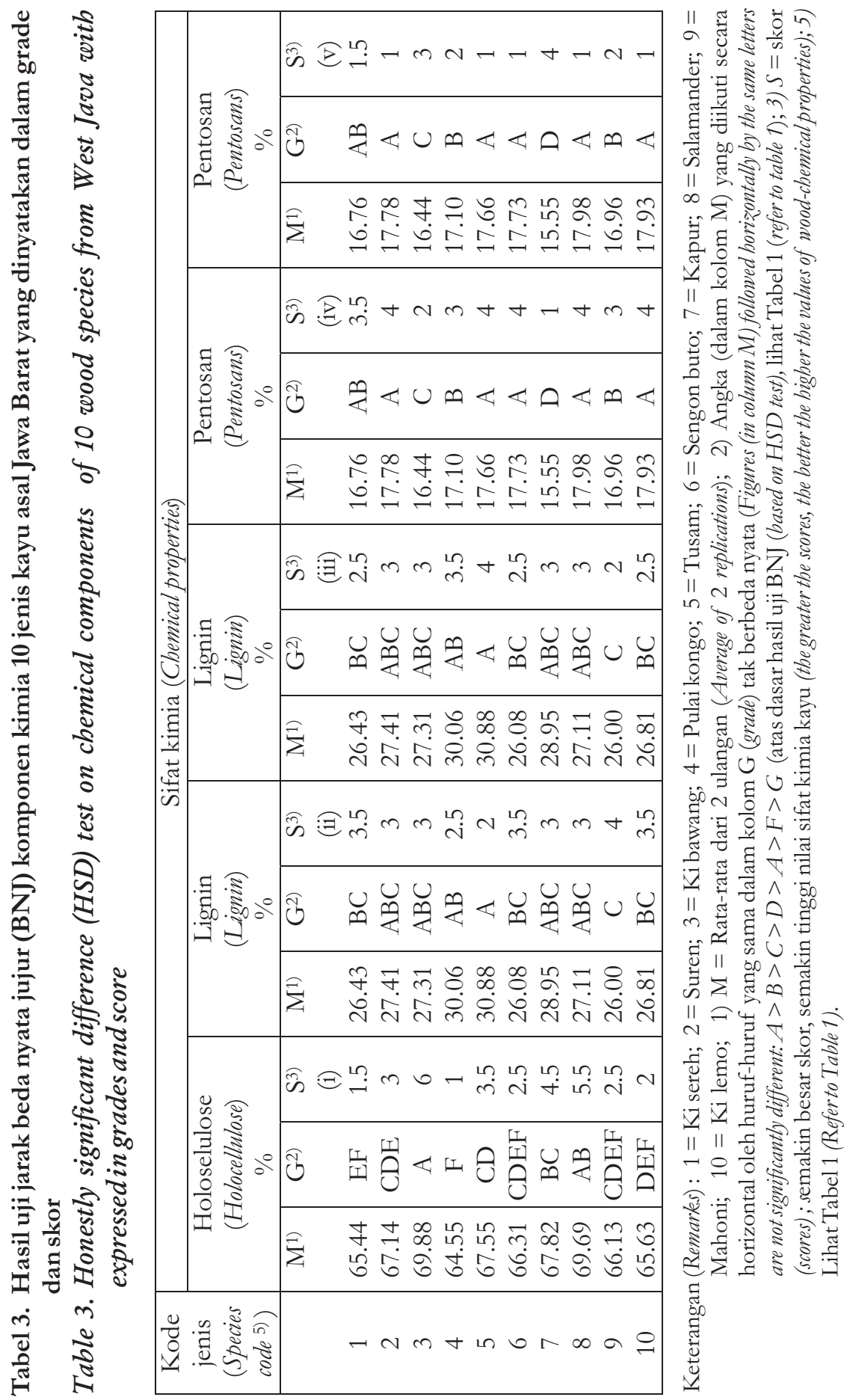


JURNAL Penelitian Hasil Hutan Vol. 24 No. 2, April 2006: 89-101

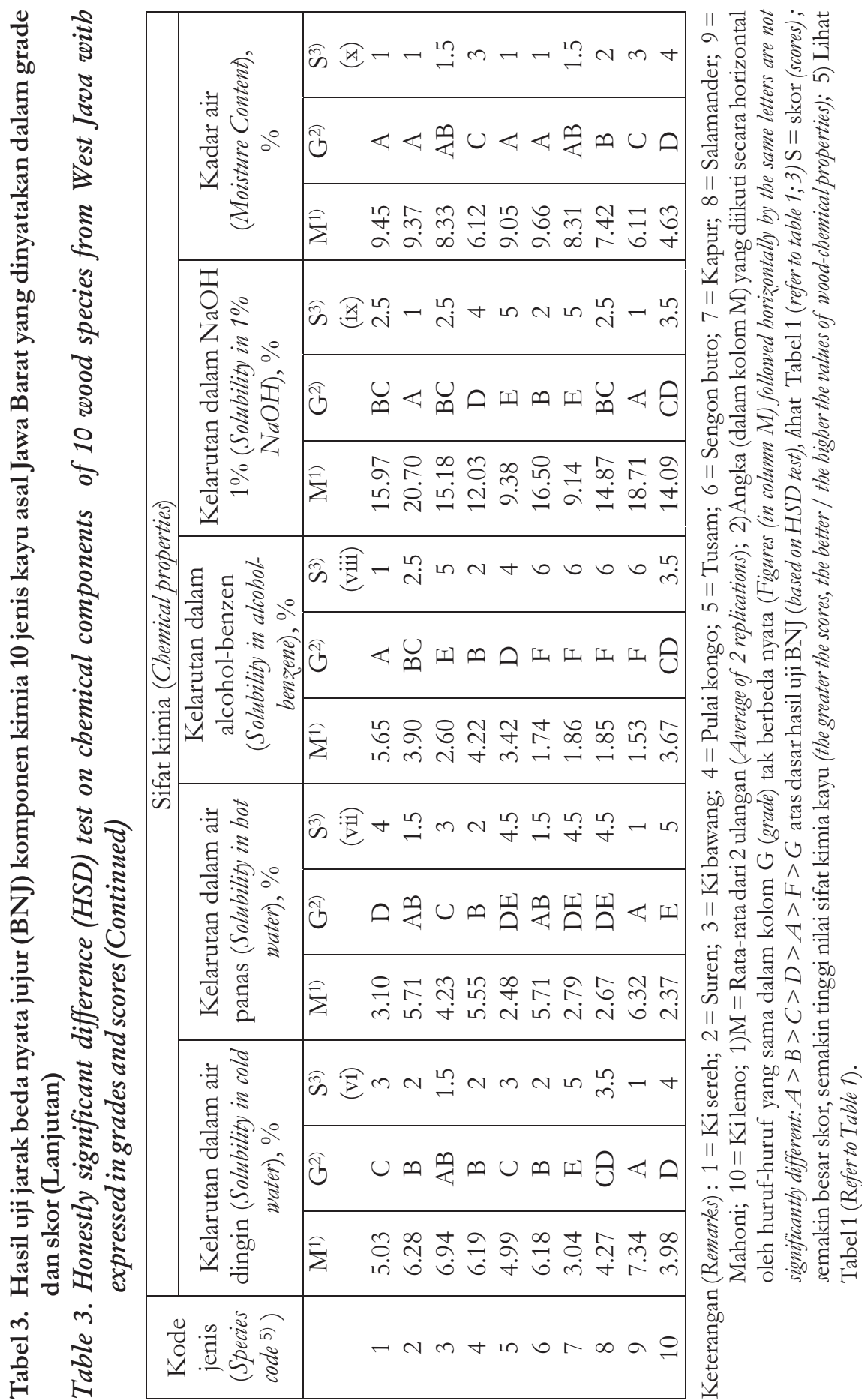


Komponen kimia sepuluh jenis kayu ... (Gustan Pari, Han Roliadi, Dadang Setiawan \& Saepuloh)

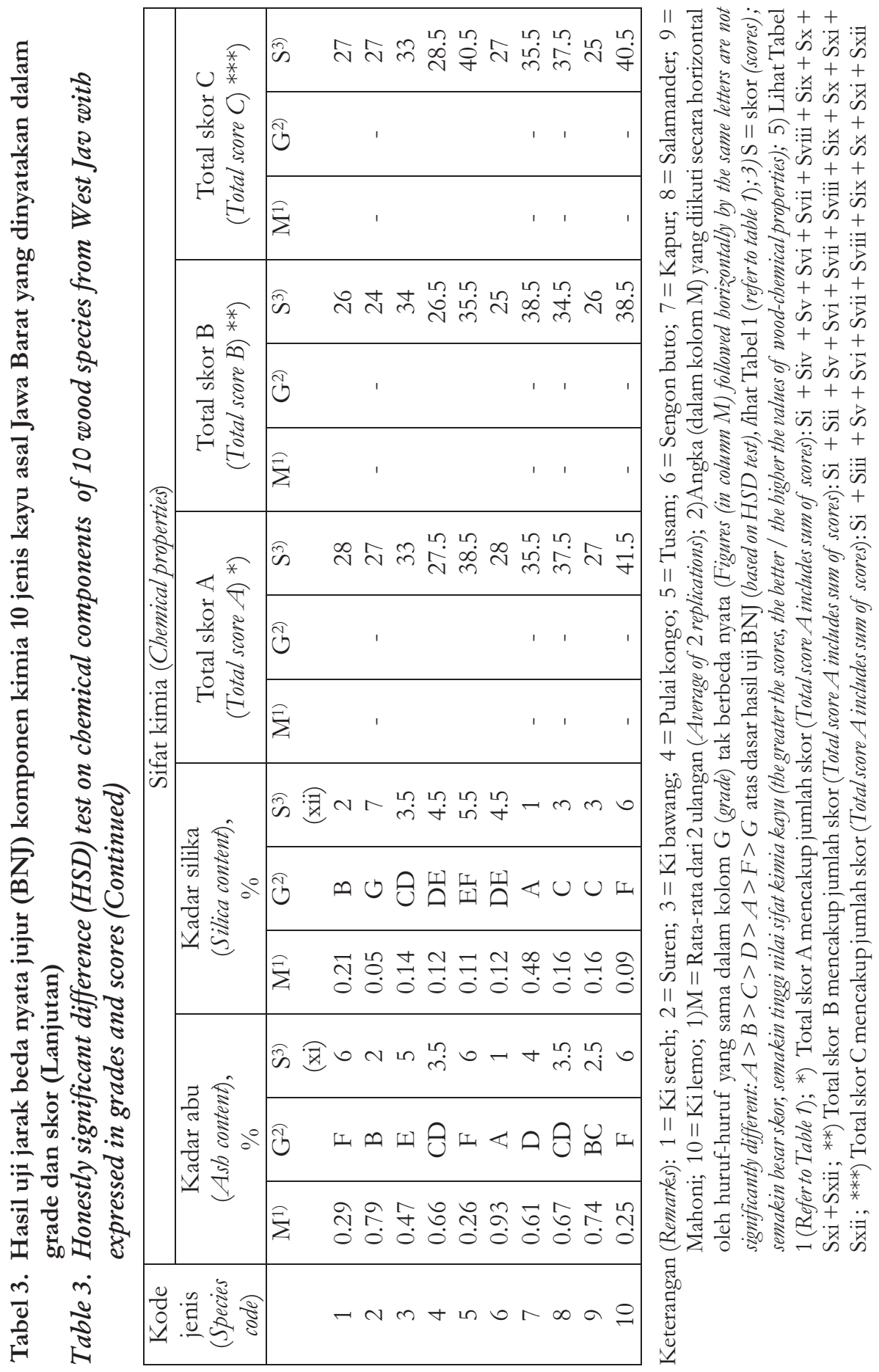

